\title{
THREE NEW PAMBOLIDS FROM THE UNITED STATES.
}

\author{
BY WM. H. ASHMEAD, WAShington, D. C.
}

Arraphis Ruthe.

No species of this interesting genus is yet described from North America and nothing is known of the habits of the several described European species.

Two distinct species, captured by myself in Florida while sweeping, and known to me only in the male sex, may be thus distinguished:-

Metanotum coarsely rugose.

Black: head yellowish.

A. americana sp. n.

Metanotum distinctly areolated.

Black; collar yellow; basal twothirds of abdomen reddish.

\section{A. minuta sp. n.}

A. americana $s p . n$. $\delta$. Length, $3 \mathrm{~mm}$. Black, shining, with a short, sparse pubescence; head and collar, reddish-yellow; basal three joints of antennae, tegulae, and legs, honey-yellow. Head transverse, rounded off behind the eyes, smooth, impunctured; eyes rounded, prominent. Mesonotum trilobed, the middle lobe somewhat rugulose, carinated at sides posteriorly, the lateral lobes shagreened. Scutellum convex, smooth, shining, with a profound crenate furrow at base. Pleurae rugose. Metathorax coarsely rugose, the angles produced into a long spine; tips of the spines yellowish; there is also a delicate carina extending from the base of each spine forward to the spiracles. Wings hyaline, the stigma and nervures brownish-yellow, the costal edge black, the recurrent nervure interstitial with the transverse cubital. Abdomen oblong-oval, black, much depressed, highly polished, and composed of but three segments, the first with a deep channel along the sides, bounded by a carina above.

Hab.-Jacksonville, Florida.

Type in Coll. Ashmead.

Described from a single specimen.

A. minuta $s p . n$. $\delta$. Length $1.4 \mathrm{~mm}$. Black, shining; collar yellow; basal twothirds of abdomen reddish, the basal half finely longitudinally striated; rest of the abdomen highly polished. Antennae long, slender, black, the pedicel and first flagellar joint alone yellowish. Thorax faintly shagreened or punctate, the mesonotum trilobed, the middle lobe with a slight impression posteriorly just in front of the scutellum but without a carina at the sides. Scutellum smooth with a faintly crenated fovea at base. Pleurae finely rugose. Metathorax regularly areolated, the angles produced into long yellow spines, the surface of the areas, except the long middle, smooth and shining, the middle area transversely wrinkled. Legs honey-yellow. Wings hyaline, the stigma and nervures pale yellow.

Hab. - Jacksonville, Florida.

Type in Coll. Ashmead.

Pambolus Haliday.

P. bifasciatus sp. $n$. $\delta$ ㅇ. Length $\& 3$ mm., ovip. $0.3 \mathrm{~mm}$; क $2.6 \mathrm{~mm}$. Black, subopaque, minutely shagreened; metathorax finely rugose and indistinctly areolated. Mesonotum without furrows. Scutellum flat with a crenate furrow across the base. Wings hyaline with two transverse, fuscous bands. Antennæ in $\delta 21-$, in $\$ 22$ - jointed, pale yellowish-brown. Legs dark fuscous, 
almost black, the tarsi pale. Abdomen a little longer than the head and thorax together, longitudinally striate, the apical margins of segments 2,3 , and 4 , apical half of 5 , and the following segments smooth, polished; the second segment has also two transverse lines or iinpressions, the first distinct situated a little beyond its basal third, the second indistinct.

Hab. - District of Columbia, Cali- fornia, and Morgantown, W. Va. Types in Coll. Ashmead and National Museum.

My specimens were taken at large, while those in the National Museum were reared June 24, I891, at Morgantown, W. Va., by Prof. A. D. Hopkins, from Anthaxia viridicornis, living in willow twigs.

\section{NOTES ON CERURA, WITH DESCRIPTIONS OF NEW SPECIES}

BY HARRISON G. DYAR, BOSTON, MASS.

The species of Cerura have been so badly mixed up in Prof. Smith's new list, that I will give a catalogue of them, as follows:

Cerura multiscripta Riley.

I8.75 - Riley, Trans. St. Louis acad. sci., iii, $24 \mathrm{I}$.

I89o-Dyar, Psyche, v, 393.

Habitat-Missouri and Illinois to New York.

Cerura scitiscripta Walker.

I865-Walk., Cat. lep. Brit. mus., xxxii, 408. var. CANDIDA Lintner.

I877 - Lintn., 3oth rept. N. Y. State mus., 199.

I89 I - Dyar, Can. ent., xxiii, 87. pr.var.

Habitat - Georgia to Kansas.

Crerura cinerea Walker.

I865 - Walk. Cat. lep. Brit. mus., xxxii, 407 .

I883-Edwards and Elliot, Papilio, iii, I30.

I89I -- Dyar, Psyche, vi, 8o.

var. CINEREOIDES Dyar.

I89o--Dyar, Can. ent., xxii, 253.

r89r - Dyar, Psyche, vi, 82.

Habitat - New York to Montana and California.

Cerura occidentalis Lintner. I 877 - Lintn., 3oth rept. N. Y. State Mus., I.94.

I88I -.- French, Can. ent., xiii, I44.
Habitat-Pennsylvania to Canada and Wisconsin.

Cerura modesta Hudson.

I89 r - Hudson, Can. ent., xxiii, I97.

Habitat - Northern New York.

Cerura borealis Boisduval.

1832-Boisd., Cuv. an. kingd., (Griffith).

I84I - Harris, Rept. ins. Mass., 306.

I 864 - Packard, Proc. ent. soc. Phil., iii, 375 .

1872 - Lintner, 26 th rept. N. Y. st. cab. nat. hist., $15 \mathrm{r}$.

I877-Lintner, 3oth rept. N. Y. st. mus., 196.

I88I - French, Can. ent., xiii, I45.

I89r - Dyar, Can. ent., xxiii, 85 .

Habitat-Georgia and Missouri to Illinois and New England states.

Cerura scolopendrina Boisduval.

s869 - Boisd., Lép. de la Cal., 86.

I891-Dyar, Can. ent., xxiii, I86.

aquilonaris Lintner.

1877-Lintn., 3oth rept. N. Y. state mus., I97.

I89 - Thaxter, Can., ent., xxiii, 34.

I89r-Dyar, Can. ent., xxiii, I86, pr. syn.

Habitat-New York, Canada, Montana, Oregon and California.*

*This is, doubtless, the species to which Butler re. ferred as C. bicuspis Bkh. in Ann. mag. n. h., viii, $3^{\mathrm{I}} 7$. 

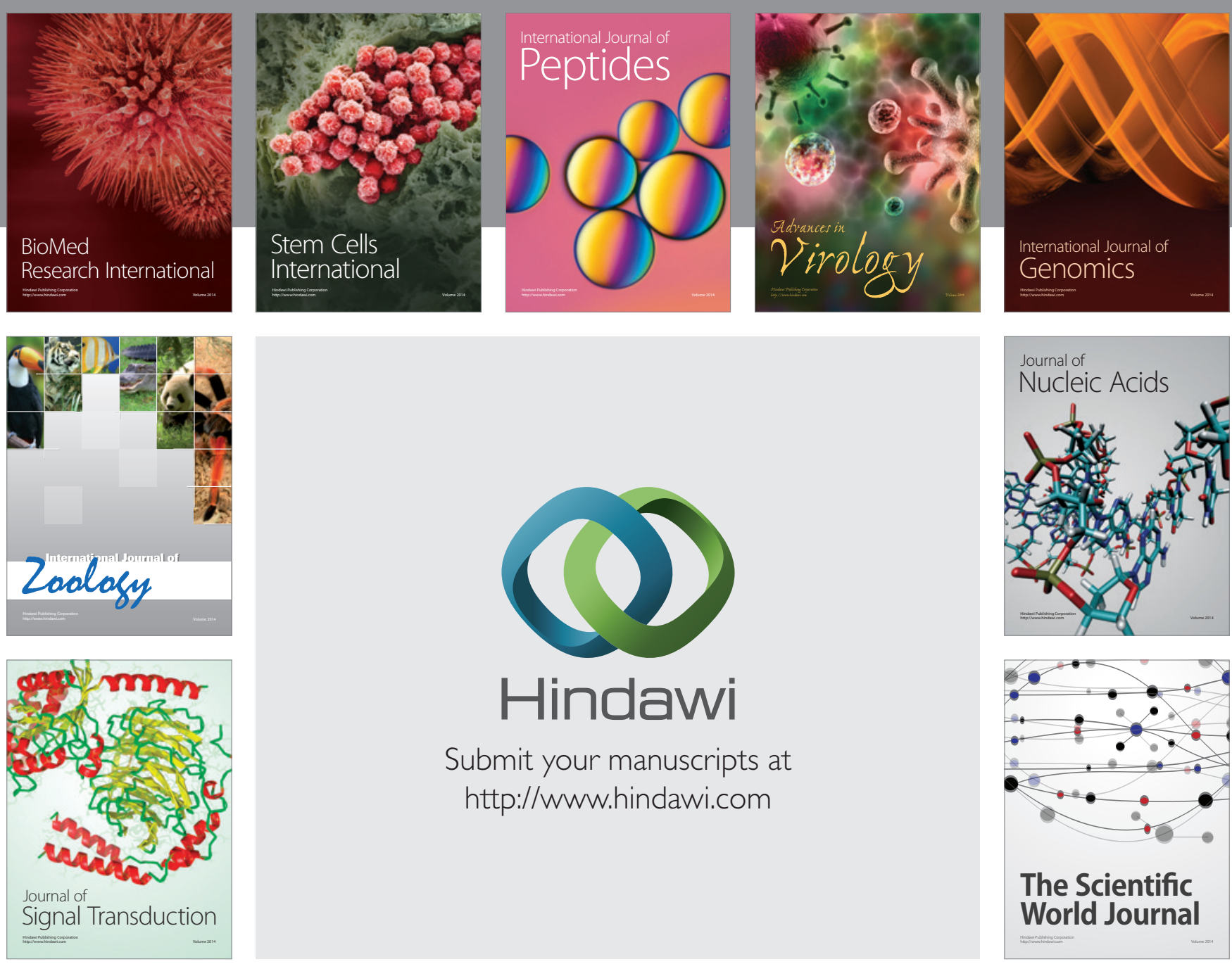

Submit your manuscripts at

http://www.hindawi.com
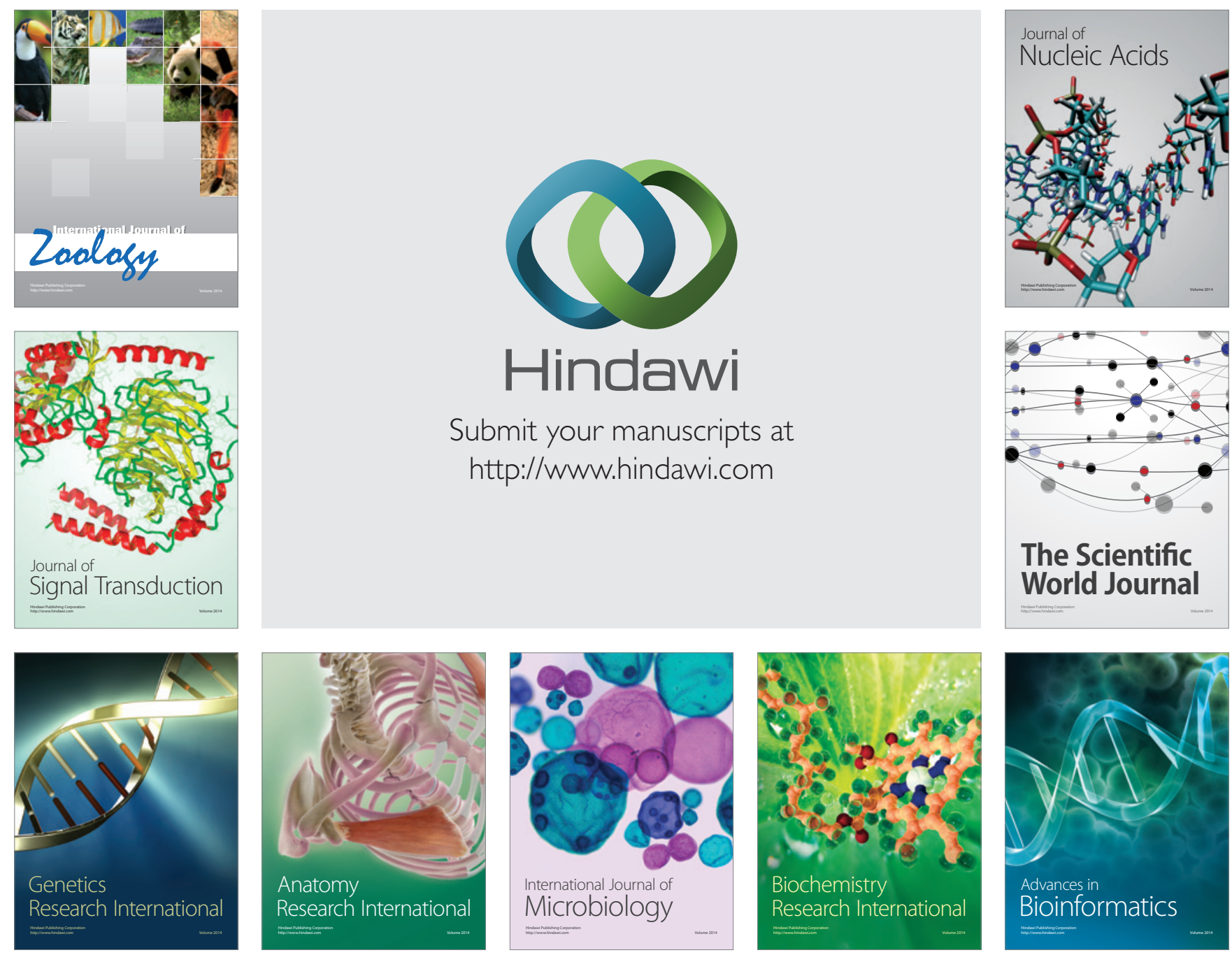

The Scientific World Journal
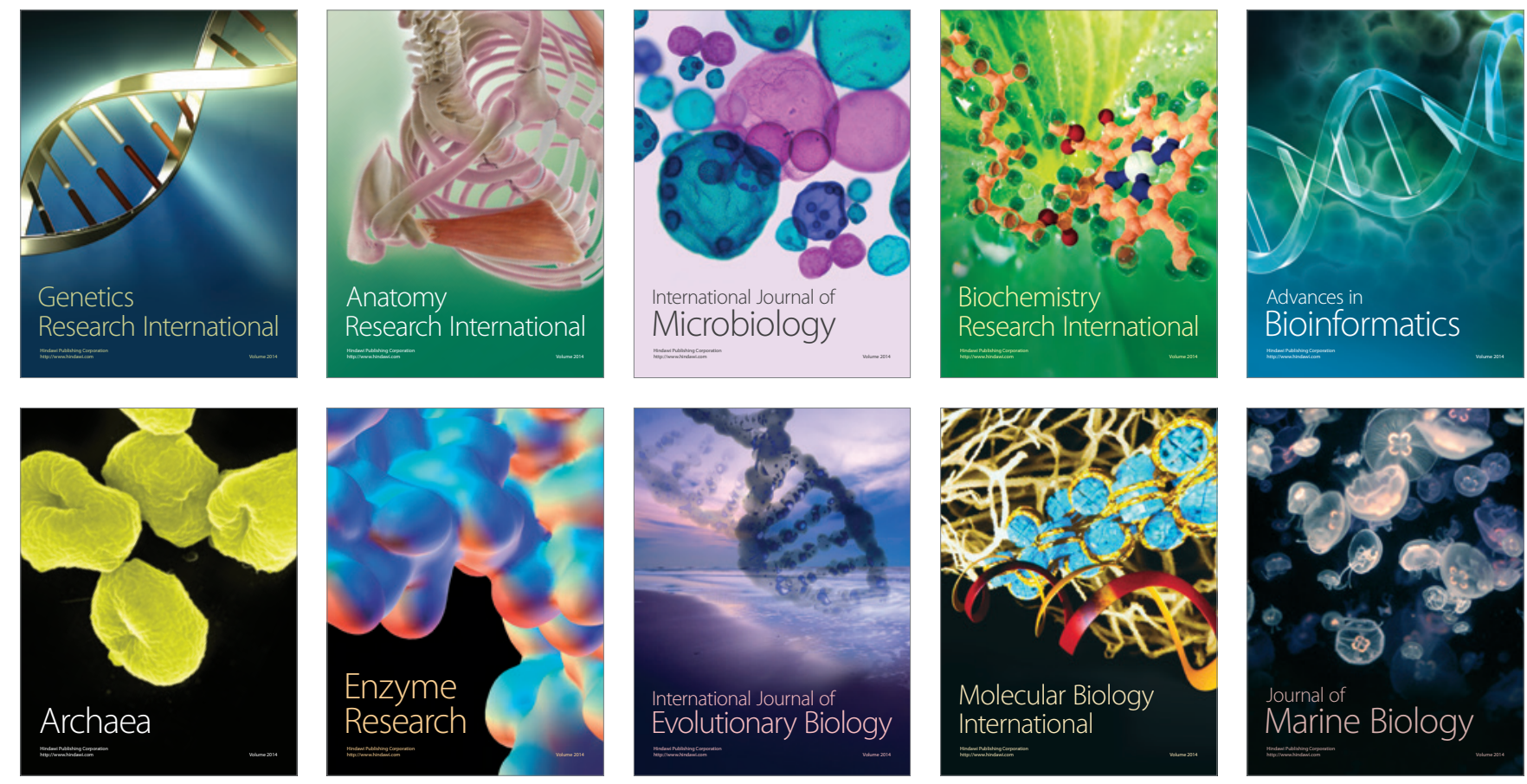